\title{
TRADITIONAL DECISION MAKING IN URBAN NEIGHBORHOODS
}

\author{
Martha G. Logsdon
}

In the course of trying to identify the role of urbanization in social and political change in the third world, social scientists have frequently addressed the phenomenon of the carry-over of "rural-traditional" patterns of behavior to the urban setting. This study looks at the methods of decision making in the neighborhoods of Jakarta based on data gathered in 1970.* It tries to answer the question, under what circumstances and for whom is the traditional system of decision making retained in the urban setting; it also offers analysis of why some citizens prefer the nontraditional methods of decision making. Two types of decisions are considered in this paper: the selection of neighborhood leaders and decisions to undertake neighborhood activities.

\section{Decision-Making Models}

This study is concerned primarily with two types of decision making. One is the majority-rule model, and the other is the unanimous-consent mode1. Decision making through majority rule assumes competing interests, with the side achieving 50 percent plus one winning and the other losing. Although a coalition of interests frequently makes up the majority, majority rule does not recognize the coalescence of all points of view as an ideal.

Decision making by unanimous consent is only reached when all sides are in agreement. Thus, it usually implies considerable discussion and compromise. But the compromise involved here is frequently viewed differently from that needed to build a coalition in the majority-rule systems. The basic assumption is that there is a common interest in society--rather than competing interests--which all sides will learn to recognize through discussion. There are no "losers" in this form of decision making, which results in the good of the whole rather than the good of the greater number.

The Europeans who colonized the archipelago introduced majorityrule decision making to Indonesia, along with other Western styles of governance. Until the institution of Guided Democracy in 1959 the national political institutions of independent Indonesia, which were copied from Western parliamentary institutions, continued to use this form of decision making.

*Financial support for the collection of data came from the NDFL and FulbrightHays Fellowship programs to which the author is grateful. This paper was originally presented in a slightly revised form at the Association for Asian Studies Meeting, 1978. 
For many of the peoples of Indonesia unanimous consent is the indigenous decision-making rule. Koentjaraningrat sees musyawarah (discussion) and mufakat (unanimous agreement arising out of discussion) as growing out of a cooperative spirit which underlies the village sense of community in most Indonesian cultures.

\begin{abstract}
An important manifestation of the gotong-rojong ethos in most Indonesian village communities is the institution of musjowarah. The concept involves the processes that develop general agreement and consensus in village assemblies, which emerge as the unanimous decision or mupakat. This unanimous decision can be reached by a process in which the majority and minorities approach each other by making the necessary readjustments in their respective viewpoints, or by an integration of the contrasting standpoints into a new conceptual synthesis. Musjowarah and mupakat thus exclude the possibility that the majority will impose its views on the minorities. Musjawarah and mipakat, however, imply the existence of personalities who, by virtue of their leadership, are able to bring together the contrasting viewpoints or who have enough imagination to arrive at a synthesis integrating the contrasting viewpoints into a new conception. 1
\end{abstract}

This tradition of musyawarah-mufakat is treated here as a rural decision-making pattern (rural because it grows out of village tradition), but, like majority rule, it has also served in national political institutions in Indonesia. Mufakat is one of the five pillars of the state in Panca Sila. And when Sukarno instituted Guided Democracy, the return to the 1945 Constitution included adoption of unanimous consent as the decision-making rule for Parliament. This change was justified as a return to a system appropriate to the Indonesian personality and as a rejection of an essentially foreign process (majority rule) which led parties to fight for their own narrow interests rather than for the good of the nation.2 This nationalist use of the concepts of musyawarah-mufakat is the ideological basis on which the government's decision to maintain the rural tradition in the urban setting rests. One might assume that such official support for the traditional system of decision making gives mufakat a better chance than most rural traditions of being retained in the urban setting.

None of this discussion is meant to address the question of the extent to which musyawarah-mufakat as an ideal is any sort of reflection of the reality in Indonesian villages today. Villages have felt the influence of many outside forces--the Dutch, changing times, urbanism itself--which have substantially altered practice in the villages so that mufakat may in many areas be mostly a remembered ideal.

As an idea1, musyawarah-mufakat is presumed to be possible because even when conflict is present, a village has a cooperative spirit and basic unity, a shared value of harmony in the public interest that might mitigate the demands of particular interests. It is frequently presumed that such conditions are absent in urban areas, that the

'Raden Mas Koentjaraningrat, ed., VilZages in Indonesia (Ithaca, N.Y.: Corne11 University Press, 1967), p. 397.

"Sukarno, "Saving the Republic of the Proclamation," in Herbert Feith and Lance Castles, eds., Indonesian Political Thinking 1945-1965 (Ithaca, N.Y.: Cornell University Press, 1970), pp. 32-89. 
relative heterogeneity of neighborhoods in Jakarta, for instance, makes the possibilities for mufakat slim indeed. Majority-rule decision making does not require the same sense of cooperation, and common value system as does a system in which all participants must agree or at least acquiesce, even when the decision harms some particular interest. Individualism is the ideal soil in which majority rule can grow, and the city has been characterized (by Louis Wirth, Robert Parh Ernest Burgess, and others of the "Chicago School" of sociology) as an environment in which the individual's relationships to the rest of society are superficial and segmentalized. Heterogeneity, it has been argued, broke down old social structures and the individual was left adrift with no consensual standards to provide informal controls on his behavior. Subsequent studies have indicated that this view of the city is a gross exaggeration; but, especially in the rapidly growing urban areas, many residents may well live in an environment which seems strange because they have been socialized under and for very different conditions.

This is certainly the case in Jakarta, Indonesia, whose population has increased by over four million in thirty years. This study looks at decision making within neighborhoods in Jakarta and tries to evaluate the extent to which traditional decision-making methods (musyawarahmufakat) are maintained and valued and the extent to which, in practice or as an ideal, they have been replaced by majority rule.

\section{Broader Theoretical Implications}

Two different sorts of literature deal with the significance of maintaining traditional decision-making ideals and practice. First, comparative political scientists have transferred many of the assumptions of the Chicago School (since discredited for American cities) to third-world cities, assuming that recent migrants are suffering from a lack of social ties and anomie, conditions likely to make them subject to social unrest or demagoguery. ${ }^{3}$ The extent to which urban communities engage in consensus decision making can shed 1 ight on the adjustment problems of urbanites, since, if a consensus on values is common, it is unlikely that members of such communities would suffer from the anomie so prevalent in the vision of the Chicago School.

A second theoretical concern with this question comes from policy impact analysis. Essentially, this is the question of the difference made by the method of decision making. Many officials, at least in Jakarta, believe that if a leader is selected by unanimous consent that leader can more effectively mobilize people for community projects, such as repairing local roads or contributing to an independence day celebration.

This study does not provide direct evidence for the outcome of the decision-making process and whether it results in social unrest or enhanced capacity for group action; but implications for these two broader theoretical questions exist within the descriptive empirical data.

${ }^{3}$ For an excellent discussion of this see Wayne A. Cornelius, Jr., "The Political Sociology of Cityward Migration in Latin America: Toward Empirical Theory," in Francine Rabinovitz and Felicity Trueblood, eds., Latin American Urban Research, Volume I (Beverly Hills, Calif.: Sage Publications, 1971), pp. 95-119. 


\section{Setting of the Study}

This study focuses both on the practice of neighborhood decision making and on the values concerning decision making held by urban citizens. The practice of decision making is studied in the process of selecting neighborhood leaders, while attitudes are measured by a question concerning the method by which community leaders ought to make decisions. Thus, basically, this study has two units of analysis--the neighborhood election and the individual whose opinion has been measured. Each of these requires some explanation.

\section{The Neighborhood}

The Capital Territory of Jakarta is administered through a multiple-tiered hierarchy of territorial units, the smallest of which is the kelurahan. Each kelurahan is further divided into units called rukun warga (RW), and these are further divided into rukun tetangga (RT). These two units are not administrative units and have no officials to staff them, but they are legally sanctioned: laws describe how they are to be constituted and how officers are to be selected.

It is with the smallest neighborhood unit that this study is primarily concerned. The rukun tetangga is a territorial unit which includes approximately forty households. The officers are selected by the heads of households, and the legally prescribed procedure for this is musyawarah-mufakat. The leader of the RT (ketua RT, usually called Pak RT when male) has two sorts of functions. Vis-à-vis the government, he or she is expected to provide a communications linkage with the neighborhood residents and be able to mobilize support for various projects to be carried out by local inhabitants. ${ }^{4}$ To the residents of the RT the leader's role varies according to the class of the neighborhood. But the ketua RT generally serves as an intermediary for individuals in dealing with the lurah (head of the kelurahan) and, in lower class neighborhoods, as a kind of father-figure for the community.

The selection process for these RT leaders will serve as one of our indicators of the decision-making process in urban neighborhoods.

\section{Individual Attitudes}

In order to measure individual opinion on the questions with which we are concerned, a sample was made of household heads by selecting fourteen of the 221 kelurahan of the Capital Territory.

The Capital Territory is an overbounded city, so some of its kelurahan are not urban in density or economic base. The sample, then, included appropriate proportions of urban and rural areas within the bounds of the Capital Territory and also took into account class and area of the city in which the kelurahan were situated. In each selected

${ }^{4}$ For a full 1isting of the purposes of the RT system, see "Surat Keputusan Gubernur/KDH DCI Djakarta no. Ib3/2/14 1966 ttg. Peraturan Dasar Rukun Tetangga dan Rukun Warga DCI Djakarta," in DCI Djakarta, Pedoman Pembinaan Wilajah dan P.M.D. Chusus DCI Djakarta, n.d. 
kelurahan, four RTs were randomly selected. In those RTs a 1 ist of all household heads was made, and approximately one-third of all household heads were randomly selected in the designated RTs. A total of 548 respondents were thus interviewed.

This sample serves as the basis for analyzing individual attitudes toward neighbo nood decision making. For this paper only the 370 urban residents of the area are included in the analysis. Figures from this sample are also used for comparative purposes on election attendance.

\section{The Selection of RT Leaders}

The legally prescribed process for recruiting personnel for the position of RT chairman is consultation (musyawarah) among all household heads of the neighborhood and unanimous agreement (mufakat) on the appropriate person to hold the position.

Legal norms are not, of course, always reflected in behavior, but in this case there seems to be considerable correspondence between the two. The fifty-seven neighborhood leaders included in the attitude survey report their selection to have occurred in the following ways: forty-seven of the fifty-seven claim to have been elected by the neighborhood (forty-five by mufakat and two by majority rule) while the other ten came to office in other ways.5 Thus 79 percent of the sample of RT chairmen report they came to office by musyawarah-mufakat.

Majority rule seems not to have made in-roads on the selection process.

Nonetheless, a form can be ostensibly maintained although the reality is very different. Musyawarah-mufakat grows out of a rural tradition and has been transplanted into the very different social conditions of an urban environment. The process of consultation until unanimity is achieved assumes a certain degree of homogeneity, within which the interests and goals of all participants coincide, so that through discussion they will realize the appropriate decision. Verba has called this the "no-conflict" assumption and has commended with regard to attempts to apply results of small group experiments to the real world that:

The assumption is valid for a large number of small experimental groups artificially insulated from external pressures. Decisions

${ }^{5}$ Two were officers who became chairmen when the former RT chairman became incapable of holding office (one was jailed for alleged involvement in the "September 30 Movement," the other moved). Four RT chairmen (all from the same kelurahan) were appointed by the lurah after some consultation with the notables of the neighborhood which left them in conflict (the lurah is very unpopular). One was appointed by the RW chairman, one was appointed by the old RT chairman when he left, one was appointed by several local leaders with no musyawarah, and one was appointed by the Japanese during the Occupation. (The latter claims that every year he tries to resign but is unable to do so because the people do not want him to). The entire selection process occurs in an atmosphere which restricts the choice of chairman to those who are not communists. And although the legal situation was very fluid as to whether communists could participate in the discussion, the trend seemed to be for them not to do so or to support the overwhelmingly popular candidate. This would be natural if they were afraid on account of their political background. 
in small face-to-face groups . . are often made on the basis of consensus rather than on the basis of formal vote and majority rule. In a small face-to-face group made up of peers and relatively isolated from external pressures, there may well be a single group goal or a single means to that goal that is in the best interests of all members. ${ }^{6}$

Geertz has shown that the no-conflict assumption is not an accurate description of what occurred in an election he observed in a Central Javanese semi-urban area supposedly carried out according to musyawarah-mufakat. On this basis he contends that musyawarah-mufakat as a political process is observed only as a ratification of decisions already reached through conflict-ridden coalition politics. ${ }^{7}$ In a sense Geertz is trying to debunk a widely held myth about Javanese village society in a situation where that myth seems only tangentially applicable. ${ }^{8}$

The basic assumptions of musyawarah-mufakat might seem even less likely to obtain in the very urban Capital Tertitory where heterogeneity of population is more the rule than the exception. Nevertheless, the legally prescribed decision-making method remains musyawarahmufakat, and at least in form it is widely followed. Determining the extent to which the election meeting actually only ratifies consensually a decision fought out behind the scenes is thus a necessary next step.

To gain insight into the extent of real consensus underlying the leadership selection process, five elections were studied. ${ }^{9}$ By attending the election meetings as well as interviewing and talking informally with people in each of the neighborhoods, an attempt was made to gauge the extent of prior "behind-the-scenes politicking." In four of the five neighborhoods it seems that there was almost no activity before the meeting. In each of these cases, after the meetings a number of people claimed there are never more than three or four appropriate people, and the decision is really one of "who to give this burden to."

In the one case where people reported considerable earlier discussion, they indicated that the lurah (a military officer in a civilian job) wanted an army private who lived in the neighborhood to be elected

'Sidney Verba, Small Groups and Political Behavior (Princeton, N.J.: Princeton University Press, 1961), p. 222.

${ }^{7} \mathrm{Cl}$ ifford Geertz, The Social History of an Indonesian Town (Cambridge: MIT Press, 1965), pp. 153-201.

${ }^{8}$ Kelurahan Sumbersari--the area of his study--was semi-urban, with a population of 7,000 inhabitants, hardly a setting in which real musyawarah might be expected to occur through a public meeting. It was made up of six dukuhan (hamlets), three of which tended to coincide with natural villages. The other three either divided or grouped natural villages. Some dukuhan had their own special character--being all santri or all abangan. While this election may well capture the essence of Mojokuto politics, it is not necessarily typical of the practice of mufakat decision making. (Ibid., pp. 155-208.)

9These elections were selected because they were the only ones I heard about in a four-month period. Four were in relatively low-class neighborhoods, while one was middle class overall. 
chairman. The plan was defeated because most people thought the lurah's choice had no claim to distinction and was, therefore, not appropriate. Instead, the meeting elected the former RT secretary (the old chairman had died), although one other name was suggested. Some feeling for the discussion can be gleaned from the following notes:

Pak Lurah attended the meeting but was not the chairman of it. As soon as the discussion about the RT chairmanship opened, the Kepala Kampung (a paid assistant to the Lurah who lived in this RT) suggested that Pak T- be considered. He was an army man and knew about security problems. Also he was young and was always home in the evenings (when most people try to transmit RT business). An older man rose and said that while Pak T- was indeed a good man, Pak A- had lived there longer and was even now serving as RT secretary. He already knew the problems of the RT, and because he was old, people valued his advice. Several others agreed that Pak A - would be a good chairman without attacking Pak T- No one else spoke for Pak $T$ - A . After several speeches for Pak A-, a young man suggested Pak R-. But nobody supported that suggestion, and another younger man stood up to say that Pak A- seemed to be everyone's choice. The Chairman of the meeting announced that unless anyone objected to Pak A-, he would be the new chairman. No one did.

The involvement of the lurah was the only exceptional element in this election. In the other four elections studied (and in innumerable others I heard reports about), some real consensus did exist regarding the appropriate candidates. In a group the size of an RT, only two or three persons emerge with the status appropriate to the office of chairman. Quite frequently some of them may not want to serve or may support the candidacy of one of the others.

Based on this limited evidence, a "consensual politics" clearly does exist in Jakarta's neighborhood units when a leader is to be chosen. The reasons for this are explored below.

In the first place the RT is a small unit and no more than thirty to fifty heads of households are eligible to participate in the election. Although this is considerably larger than the groups studied by small group theorists like Verba, not everyone participates who is eligible to do so. In the five elections studied, the following numbers were present:

$$
\begin{array}{llll}
\text { 1. } & 22 \text { of } 40 \text { eligible members }(55 \text { percent }) \\
\text { 2. } & 25 \text { of } 39 \text { eligible members }(64.1 \text { percent }) \\
3 . & 10 \text { of } 35 \text { eligible members }(28.5 \text { percent }) \\
\text { 4. } & 15 \text { of } 37 \text { eligible members }(40.5 \text { percent) } \\
5 . & 24 \text { of } 36 \text { eligible members }(66.6 \text { percent })
\end{array}
$$

In meetings of this size, ranging from ten to twenty-five, it is conceivable for discussion to lead to consensus if other social conditions prevail. From our interviews with RT chairmen, it is apparent this is the usual group size for elections and in such small units people would know each other and their relative status. In the sample of Jakarta urban residents 62 percent reported that they attended the last RT election they heard about. 
Social conditions in urban neighborhoods are certainly different from those of rural villages, but this does not necessarily imply a cleavage politics. While urban neighborhoods are no doubt ethnically more heterogeneous, they are fairly homogeneous in terms of class. Furthermore, the higher rate of mobility in urban areas may actually discourage the development of deep and lasting cleavages such as those that Geertz found in Sumbersari. There is very little organized politics within the unit of the RT even though its members may be quite active in political parties or interest groups at higher levels. Either the RT is too small to generate such politics or the issues with which it deals cut across the interests reflected at other levels.

But another reason for the possibility of consensual politics within the RT is that for most people the stakes involved in the selection of a leader are low. The Javanese lurah (again, to use Geertz's example) usually gains considerable economic advantage from his office through control over village land and other sources of income. The RT chairman, on the other hand, gains little in concrete terms by his willingness to serve. The sums of money he is legally allowed to collect from his neighbors for such services as preparing letters and permits probably do not even cover the costs of paper and ink. The extralegal money he may try to collect as "cigarette money" (uang rokok), while perhaps a burden or minor irritation to those he serves, is not really enough to motivate anyone to fight for the office. ${ }^{10}$ Too many of his tasks as RT chairman offer no financial reward at all.

What, then, does the RT chairman get for what may be a very timeconsuming job? The best answer seems to be prestige and occasionally the satisfaction of feeling a sense of noblesse oblige. In a way it is not the prestige which comes from the office but rather a public confirmation of prestige or the respect already accorded a person that repays him for his time and energy. Virtually no RT chairman claimed to be in office for any other kind of benefit (not surprisingly), but neither did his neighbor-constituents see the job as providing much more than a title and position of respect. Let us listen to some comments by RT chairmen about why they accepted the job.

Somebody around here must be chairman, and people around here think I can do the job best.

I was chosen at the meeting even though I wasn't there because my wife was giving birth to our son. I decided to accept even though I don't have much spare time because it is an honor to be chosen. It shows that people respect (hormat) me.

Even though it takes a lot of time (makan waktu), I accepted because someone must serve the people as chairman, and I work in an office, so I know office procedures. A lot of people in this RT cannot even read or write. Those of us who can have to take on extra responsibilities.

Selection is a confirmation of status, it seems, and a common understanding on the social status system is a very important element

100 those living in urban areas 55.2 percent of the individuals sampled report they expect to pay nothing for the RT chairman's help, 29 percent more expect to pay less than Rp.50 (12\$), while 16 percent expect to pay more than Rp.50. 
in producing consensus on who shall be the leader. A majority of Indonesia's cultures, especially those most represented in Jakarta's population, have a very well-developed sense of "place." To function in virtually every setting a person must know who is the social superior and who the interior. An individual who holds a position for which his status is not arpropriate is frequently seen as ridiculous. In a small, face-to face environment such as an RT only a few individuals would be perceived as appropriate to hold the office of leader.

The smallness of the unit, the face-to-face relationships among neighbors, and the absence of lasting social cleavages or organized political groups at such a low level, together with the low stakes of the office itself, and the Indonesians' we11-developed concept of place add up to a situation in which the no-conflict or at least low-conflict assumption may be valid for the leadership selection process.

A final and formalistic explanation for why consensus is possible lies in the format of the elections, i.e., a public meeting, in the context of cultural traditions some of which encourage the appearance of harmony.

Even though a particular individual may be unhappy with the developing consensus and might theoretically be able to prevent a decision by persevering in support for his own candidate, once a large number of the small face-to-face group seems agreed, the pressure on a dissenter to acquiesce is very great. For most Indonesians it is very difficult to speak against someone, because that action violates cultural norms of appropriate behavior. ${ }^{11}$ Harmony is more highly valued than "winning," and a person who refuses to concede for the sake of the appearance of harmony is frequently poorly thought of. Thus, a lone dissenter will feel too embarrassed or ashamed (malu) to pursue his disagreement with a developing consensus. In addition, should an individual long persist in opposing a person clearly supported by the group as a whole, it would be very difficult later for the individual to seek the assistance of the leader. Thus, unanimity becomes possible.

One might say that unanimity is possible, in part, because anonymity is not. The lack of secrecy in the musyawarah-mufakat situation means that the individual is not isolated from the pressures and hierarchical influences of the community. Stein Rokkan has described the sublime isolation of the person with a secret ballot:

. . The individual adult is cut off from all his roles in the subordinate systems of the household, the neighborhood, the work organization, the church and the civil association and set to act exclusively in the abstract role as a citizen of the overall political system. There will be no feed-back from what he does in this anonymous role to what he does in the other roles and therefore no need

${ }^{11}$ The value placed on the appearance of harmony is an important value among the major cultures in Indonesia. Obviously it is not the only one. Real conflicts run very deep in the society and given a situation where high stakes are involved can break out into the open, as in the massive killing that occurred in the months following the events of October 1, 1965. But many observers were caught by surprise that such violent conflict could occur, especially among the seemingly placid, polite Javanese. 
for him to take responsibility for the act of voting in his everyday interactions in his regular environment. ${ }^{12}$

Open consultation is the very opposite of this and thus the individual is not "free" to act as he might in isolation.

For a11 the above mentioned reasons, some consensus can usua11y be reached on the selection of a leader of the RT in Jakarta at least without undue conflict.

\section{Individual Attitudes toward Community Decision Making}

Other kinds of community decision making give a more mixed picture regarding the maintenance of the ideal of unanimous consent. Urban Jakarta residents selected for inclusion in the sample were asked the following question:

Sometimes in a certain RT there is a proposal for a new activity, but not all members of the RT agree with that activity. What is the best thing for a neighborhood chairman to do in such a situation: wait until everybody is in agreement and only then begin to act, pay attention to all kinds of opinions from each side and then decide himself, or put into effect the wishes of the majority of members? ${ }^{13}$

Table 1 presents the responses of the urban respondents in the sample to this question.

Table 1

Procedure Preference for RT Decision Making in the Urban Sample

\begin{tabular}{|c|c|c|}
\hline & $\%$ & $\mathrm{~N}$ \\
\hline Wait for agreement (mufakat) & 31.9 & 118 \\
\hline Decide himself & 18.1 & 67 \\
\hline Majority opinion & 46.5 & 172 \\
\hline Other solution & 3.5 & 13 \\
\hline Total & 100.0 & 370 \\
\hline
\end{tabular}

From this table it appears that in this instance mufakat is less popular a solution than majority rule, though more popular than decision by the leader. Seemingly, majority rule, which politicians like to characterize as foreign to the Indonesian personality, has considerable popularity among urban-dwellers. While we have no good data on

12Stein Rokkan, "The Comparative Study of Political Participation: Notes toward a Perspective on Current Research," in Charles F. Cnudde and Deane E. Neubauer, eds., Empirical Democratic Theory (Chicago: Markham Publishing Co., 1969), p. 356.

${ }^{13}$ The alternatives were presented in the following way: "Tunggu sampai semuanya setuju (mufakat), baru mulai bertindak; memperhatikan segala macam pendapat dari setiap pihak, lalu memutuskan sendiri, atau melaksanakan kemauan kebanyakan anggota?" The interviewers were instructed to use the word mufakat in relation to the first alternative after the pre-tests showed that this clarified the question for respondents. 
the popularity of majority rule among rural people, 14 it does seem that the traditiona1, rural-based procedure which the government supports is not as popular as the "foreign" procedure in Jakarta's neighborhoods. In order to understand the process better, it is necessary to $100 \mathrm{k}$ at what kind of citizen prefers which method of decision making.

What might one hypothesize about who will prefer the triditional mufakat method and who the other solutions? One might suppose that the more recent migrants to the city would prefer the more traditional method since they might be deemed to be closer to their rural origins than long-time residents of the city. One might hypothesize that older residents would be more in favor of mufakat than younger residents, on the grounds that aging is frequently associated with conservatism and youth might be more attracted to the more "modern" majority rule. One might hypothesize that ethnicity will make some difference. Perhaps the Javanese with their tremendous emphasis on harmony could be expected to be more mufakat-oriented than other ethnic groups. One might hypothesize that higher educational levels and contact with the mass media (both perhaps indicators of participation in the "modern" sector and both frequently assumed to be a by-product of urbanization) will be associated with a preference for majority rule. Finally, one might thus assume that the higher one's class the more one is aware of "foreign" ideas and the more one might participate in an "urban culture" which rejects rural-based traditions. Each of these hypotheses will be considered in turn to try to clarify the conditions under which mufakat as an ideal survives.

Table 2

Length of Urban Residence and Preferred Procedure

\begin{tabular}{lccccc}
\hline \hline \multirow{2}{*}{$\begin{array}{c}\text { Preferred } \\
\text { Procedure }\end{array}$} & $\begin{array}{c}\text { Less than } \\
\text { Y Years }\end{array}$ & $5-10$ & $11-15$ & $\begin{array}{c}15+\text { but Not } \\
\text { Born Here }\end{array}$ & $\begin{array}{c}15+\text { and } \\
\text { Born Here }\end{array}$ \\
\cline { 2 - 6 } & $20.0 \%$ & $34.0 \%$ & $39.1 \%$ & $29.1 \%$ & $35.5 \%$ \\
Wait for agreement & 6.7 & 16.0 & 17.4 & 21.2 & 18.3 \\
Decide himself & 63.3 & 48.0 & 39.1 & 46.4 & 44.1 \\
Majority rule & 10.0 & 2.0 & 4.3 & 3.3 & 2.2 \\
Other solution & $(30)$ & $(50)$ & $(46)$ & $(151)$ & $(93)$ \\
N = 370 & $x^{2}$ is not significant at .50 & \\
\hline
\end{tabular}

Table 2 presents the results of the cross-tabulation of the preferred decision-making procedure with the length of time the individual has 1 ived in Jakarta. This table indicates that length of residency has no statistically significant relationship with the preferred decision-making method. Far from showing the recent migrant to prefer the traditional method, those in the city less than five years seem to prefer majority rule over mufakat more than the others.

${ }^{14}$ The rural population included in this survey is in no way typical of rural areas in Indonesia both because it is so close to a large urban area and because it is made up for the most part of the ethnic Betawi. In this rural sample 48 percent preferred mufakat, 35 percent preferred majority rule and 16 percent preferred that the leader decide. 
Table 3

Age and Preferred Procedure

\begin{tabular}{lcccr}
\hline \multirow{2}{*}{$\begin{array}{l}\text { Preferred } \\
\text { Procedure }\end{array}$} & Under 30 & $30-40$ & $41-60$ & $61+$ \\
\cline { 2 - 5 } & $25.0 \%$ & $34.5 \%$ & $33.6 \%$ & $29.4 \%$ \\
\hline Wait for agreement & 13.2 & 18.6 & 19.1 & 29.4 \\
$\begin{array}{l}\text { Decide himse1f } \\
\text { Majority rule }\end{array}$ & 57.9 & 44.1 & 43.5 & 41.2 \\
Other solution & 3.9 & 2.8 & 3.8 & .0 \\
$\mathrm{~N}=369$ & $(76)$ & $(145)$ & $(131)$ & $(17)$ \\
& $\mathrm{x}^{2}$ not significant at .5913 & \\
\hline
\end{tabular}

Table 3 indicates that age is a1so not significantly associated with preference for the rural-based tradition. The oldest people seem somewhat more willing to leave the decision to the leader and the youngest seem to like majority rule more than the other categories, but the total relationship is not statistically significant.

Table 4

Ethnicity and Preferred Procedure

\begin{tabular}{|c|c|c|c|c|c|c|c|}
\hline \multirow{2}{*}{$\begin{array}{l}\text { Preferred } \\
\text { Procedure }\end{array}$} & \multicolumn{7}{|c|}{ Ethnicity } \\
\hline & Betawi & Javanese & Sundanese & Sumatran & $\begin{array}{l}\text { Other } \\
\text { Indon. }\end{array}$ & $\begin{array}{l}\text { Other } \\
\text { Foreign }\end{array}$ & Chinese \\
\hline $\begin{array}{l}\text { Wait for agreement } \\
\text { Decide himself } \\
\text { Majority rule } \\
\text { Other solution }\end{array}$ & $\begin{array}{l}37.7 \% \\
16.4 \\
44.3 \\
1.6\end{array}$ & $\begin{array}{l}32.6 \% \\
20.6 \\
43.3 \\
3.5\end{array}$ & $\begin{array}{l}28.8 \% \\
19.2 \\
50.7 \\
1.4\end{array}$ & $\begin{array}{l}41.9 \% \\
16.3 \\
37.2 \\
4.7\end{array}$ & $\begin{array}{l}18.8 \% \\
31.3 \\
43.8 \\
6.3\end{array}$ & $\begin{array}{c}14.3 \% \\
0.0 \\
85.7 \\
0.0\end{array}$ & $\begin{array}{c}20.7 \% \\
6.8 \\
62.1 \\
10.3\end{array}$ \\
\hline \multirow[t]{2}{*}{$N=370$} & $(61)$ & $(141)$ & $(73)$ & $(43)$ & $(16)$ & $(7)$ & (29) \\
\hline & \multicolumn{7}{|c|}{$x^{2}$ not significant at .2366} \\
\hline
\end{tabular}

A1though it might have been assumed that ethnicity would influence individual attitudes on neighborhood decision making because of the varying emphasis placed by different cultures on unanimous consent, Table 4 indicates that it is not statistically significant. The highest support for mufakat comes from the various ethnic groups from Sumatra. Al1 these Sumatran groups were collapsed into one category because they made up such a small part of the sample. The Javanese, who might be expected to show strong support for mufakat, in fact preferred majority rule, as did every group but the Sumatrans.

Lerner, in his attempt to develop an empirically based theory of "modernization," suggested that increasing urbanization has tended to result in higher literacy rates, which in turn have led to greater participation in the mass media. For Lerner the significance of the mass media lies in its ability to enable people to imagine themselves in situations they have not experienced, a condition he equates with "modernity" and which he believes will ultimately lead to the demand 
for political participation and ultimately electoral participation.15 If Lerner's model is accurate, one might expect that those who read newspapers will be less inclined to favor the traditional system of decision. Caught up in the broader world and participating in the "modern way of life" one might expect to see majority rule as most popular with these urban-dwellers.

Table 5

Newspaper Readership and Preferred Procedure

\begin{tabular}{lcccc}
\hline \multirow{2}{*}{$\begin{array}{c}\text { Preferred } \\
\text { Procedure }\end{array}$} & \multicolumn{4}{c}{ Number of Newspapers Read } \\
\cline { 2 - 5 } & None & 1 & 2 & 3 or More \\
\hline Wait for agreement & $34.5 \%$ & $35.4 \%$ & $21.2 \%$ & $35.8 \%$ \\
Decide himself & 11.8 & 16.8 & 25.9 & 22.6 \\
Majority rule & 52.9 & 45.1 & 45.9 & 35.8 \\
Other solution & 0.8 & 2.7 & 7.1 & 5.7 \\
N $=370$ & $(119)$ & $(113)$ & $(85)$ & $(53)$ \\
& $x^{2}$ significant at .0253 & \\
\hline
\end{tabular}

However, the data suggests just the opposite is the case. As Table 5 shows, majority rule is most popular for neighborhood decision making among those who report reading no newspapers. The number of newspapers read does not seem to influence the preference for mufakat. The real difference 1 ies in the increased popularity of letting the leader decide himself, which (contrary to what one would expect in Lerner's model) is most popular among those who read two or three newspapers. The relationships are statistically significant. When all non-readers are excluded, the frequency of newspaper reading is not statistically significant, as Table 6 illustrates.

Table 6

Frequency of Readership and Preferred Procedure

\begin{tabular}{lccc}
\hline \hline \multirow{2}{*}{$\begin{array}{c}\text { Preferred } \\
\text { Procedure }\end{array}$} & \multicolumn{3}{c}{ How Often Newspapers are Read } \\
\cline { 2 - 4 } & Daily & $\begin{array}{c}\text { Twice a } \\
\text { Week }\end{array}$ & $\begin{array}{c}\text { Once a Week } \\
\text { or Less }\end{array}$ \\
\hline Wait for agreement & $32.0 \%$ & $33.3 \%$ & $26.2 \%$ \\
Decide himself & 20.7 & 15.2 & 24.6 \\
Majority rule & 41.3 & 45.5 & 49.2 \\
Other solution & 6.0 & 6.1 & 0.0 \\
$\mathrm{~N}=248$ & $(150)$ & $(33)$ & $(65)$ \\
& $x^{2}$ not significant at .4102 & \\
\hline
\end{tabular}

15Daniel Lerner, The Passing of Traditional Society (New York: The Free Press, 1958), p. 60. 
Newspaper readership might, of course, simply be a surrogate for education, or education might have an independent effect. Ignoring for the moment the multi-collinearity problem, Table 7 presents the relationship between education and preference for neighborhood decisionmaking procedures.

Table 7

Education and Preferred Procedure

\begin{tabular}{lccccccc}
\hline \multicolumn{1}{c}{$\begin{array}{c}\text { Preferred } \\
\text { Procedure }\end{array}$} & None & $\begin{array}{c}1-3 \\
\text { Years }\end{array}$ & $\begin{array}{c}4-6 \\
\text { Years }\end{array}$ & $\begin{array}{c}7-9 \\
\text { Years }\end{array}$ & $\begin{array}{c}10-12 \\
\text { Years }\end{array}$ & $\begin{array}{r}\text { College } \\
\text { not Grad. }\end{array}$ & $\begin{array}{c}\text { College } \\
\text { Grad. }\end{array}$ \\
\cline { 2 - 7 } & & & & & \\
Wait for agreement & $40.9 \%$ & $37.8 \%$ & $27.9 \%$ & $27.4 \%$ & $25.4 \%$ & $38.5 \%$ & $40.5 \%$ \\
Decide himself & 11.4 & 2.7 & 15.4 & 24.2 & 22.0 & 34.6 & 21.6 \\
Majority rule & 47.7 & 51.4 & 54.8 & 43.5 & 49.2 & 23.1 & 32.4 \\
Other solution & 0.0 & 8.1 & 1.9 & 4.8 & 3.4 & 3.8 & 5.4 \\
N = 369 & $(44)$ & $(37)$ & $(104)$ & $(62)$ & $(59)$ & $(26)$ & $(37)$ \\
& & $x^{2}$ significant at .0546 & & & \\
\hline
\end{tabular}

The relationship presented here is statistically significant. Close examination of this table reveals some anomalies. Those who have attended at least some college and those who have had no education are the strongest supporters of mufakat. While one might expect the college educated to be the least traditional in views, here that is not the case. This could possibly be the result of political education in colleges where (especially during the Sukarno period) great emphasis was put on nationalist values, including mufakat.

The other way in which education seems to make a difference is in the slightly greater popularity of the least "participant" option (in Lerner's sense), that of leaving the decision to the leader. Majority rule is least popular with the college educated. Of course, education and class are closely related, so the relationship between class and decision-making values is presented in Table 8 to help clarify what is going on.

Table 8

Class and Preferred Procedure

\begin{tabular}{llccc}
\hline \multirow{2}{*}{$\begin{array}{c}\text { Preferred } \\
\text { Procedure }\end{array}$} & Upper & Middle & Lower & Very Low \\
\cline { 2 - 5 } & $38.2 \%$ & $33.1 \%$ & $28.0 \%$ & $37.0 \%$ \\
Wait for agreement & 23.5 & 23.1 & 16.0 & 3.7 \\
Decide himself & 32.4 & 38.5 & 53.7 & 59.3 \\
Majority rule & 5.9 & 5.4 & 2.3 & 0.0 \\
Other solution & $(34)$ & $(130)$ & $(175)$ & $(27)$ \\
N = 366 & $x^{2}$ significant at .0494 & \\
\end{tabular}


As Table 8 indicates, the relationship is statistically significant. Mufakat is the choice of a roughly similar proportion of all classes (though slightly more preferred by the highest and the lowest classes). However, the lower one's class, the more majority rule is preferred, and the upper classes are far more likely than the lowest class to choose the option of letting the leader decide.

What explains this pattern, which is quite contrary in many respects from the expected results? Class as measured here is a generalized "style-of-Iife" indicator. The Interviewer who was an indigenous Indonesian judged class on the basis of the respondent's home, furniture, appliances, neighborhood, and education. In short, class is a measure of status as much as wealth. To understand the results on class, and indeed the results from the other tables as well, it is necessary to reexamine the status situation in the neighborhood.

Our question did not specify what precisely the decision to be made was. Thus, the stakes involved are unclear. To a Jakartan, though, the kinds of decisions likely to be made in a neighborhood are wel1-known, and to outsiders they may be trivial. Shall we have a neighborhood celebration for Independence Day? Should we all get together Sunday morning and repair the holes in the dirt road? Should we all contribute ten cents to buy some books for the new reading room?

The participants' estimate of the significance of the decisions depends on their relative position in the system. Contributing funds is not nearly so significant to the upper as to the lowest class. And perhaps one could postulate that the upper classes prefer to leave decisions to the leader because RT affairs strike many of them as unimportant and not worth wasting time on. This is much less true as one moves down the class scale.

The popularity of majority rule among the lower classes remains to be explained. An absolute majority of the two lowest classes preferred it, despite the fact that they are the least educated and the least likely to read newspapers, and thus one might expect, the least likely to have "foreign" values. Why might the poorest be least "traditional" in the urban setting?

The answer which seems most consistent with the data 1 ies in an analysis of the benefits the different classes derive from each sort of decision making. The poor are generally a majority in their neighborhoods. But under mufakat it is quite possible that final decisions will not represent their interests, as the winner is likely to be the person who maintains his position longest. Because of their strong sense of appropriate behavior, many participants would find it very difficult openly to oppose the opinion of a status superior. The result of a mufakat system is, thus, often to advance the interests of the higher status individuais, perhaps at the expense of the majority. These higher status people would therefore have an interest either in maintaining mufakat, or, in a trivial matter, allowing the leader to decide.

Neighborhood decision making about activities must be differentiated from decisions on leadership selection. In leadership selection the same sense of "place" serves to produce the possibility of unanimity, as those viewed as inappropriate usually do not aspire to office. 
But on issue decisions where individual stakes, especially for the poor person, may be higher, majority rule seems preferable. It protects the interests of the lower status people without requiring any one individual to oppose personally the will of a social superior or act in an inappropriate way.

Such an interpretation, of course, implies that no basis exists for real consensus on issues when the stakes are perceived as significant, in that the urban neighborhood may be too diverse to sustain the no-conflict assumption. From these data it seems reasonable to conclude that class interests serve as the best explanation for holding a particular opinion on decision making. The only other variables significantly associated with preferred decision-making procedure were number of newspapers read and education. The direction of each of these is the same as the class data, suggesting that it is class style of 1 ife rather than the kind of effect Lerner expects which is producing the noted effect.16

Because class is a sort of summary variable for a style of 1 ife of which education and media participation are a part, it is impossible to sort out empirically exactly what is happening. The status explanation is only a beginning, and its implications for the political system are unclear.

\section{Conclusion}

The government of the Capital Territory of Jakarta has attempted to sustain the practice of a rural decision-making process in a setting where the basic assumptions of the process seem not to obtain. We have looked at reasons why the rural decision-making system has continued to work for the selection of neighborhood leaders, but we have also seen that majority rule is frequently favored as a decision-making process on neighborhood issues especially among those low in the status system. The urban setting affects the selection of decision-making procedures, but the choice between tradition-maintenance and change is somewhat more complex than some social theorists have described.

${ }^{16}$ This could be expressed more precisely in terms of the probable existence of a multi-collinearity problem where length of residence, low newspaper readership, education, and class are related to one another. Here we are offering the interpretation that class is a sort of summary variable which includes the others. 